\title{
TENDERING AND PURCHASING LAW IN UPSTREAM OIL, GAS, AND OILSANDS: THE COMPETITIVE BIDDING PROCESS AND OBLIGATIONS WHEN CONTRACTING FOR WORK
}

\author{
JANiCE BUCKINGHAM, PAULA OLEXIUK, ${ }^{* *}$ \\ TERRA NICOLAY, ${ }^{* * *}$ AND LAWNA HURL ${ }^{* * * *}$
}

This article provides owners, and particular oil, gas, and oilsands producers, with an overview of various procurement processes and specific suggestions on how owners can structure such processes, draft tender documents to meet their goals, and avoid the liability that often arises out of the tendering process. In particular, the scale and cost of oil, gas, and oilsands projects, as well as the change in market conditions, raise new issues in the procurement context that owners should consider. The article concludes with a discussion of joint ventures, the Companies' Creditors Arrangement Act process, and project liability.
Cet article donne aux propriétaires, et à certains producteurs pétroliers et gaziers ainsi qu'à des producteurs des sables bitumineux, un aperçu des divers processus d'acquisition et des suggestions spécifiques sur la manière dont les propriétaires peuvent structurer ces processus et préparer les documents de l'appel d'offres afin d'atteindre leurs objectifs et éviter ainsi la responsabilité qui découle souvent $d u$ processus d'appels d'offres. Tout particulièrement, l'importance et le coût des projets pétroliers, gaziers et des sables bitumineux hormis le changement des conditions du marché, soulèvent de nouvelles questions dans le contexte de l'acquisition dont les propriétaires doivent tenir compte. Cet article se termine par une discussion sur les coentreprises, le processus de la Loi sur les arrangements avec les créanciers des compagnies et la responsabilité à l'égard du projet.

\section{TABLE OF CONTENTS}

I. INTRODUCTION . . . . . . . . . . . . . . . . . . . . . . . . . . . . . . . . . . 498

II. General PRINCIPLES $\ldots \ldots \ldots \ldots \ldots \ldots \ldots \ldots \ldots \ldots \ldots \ldots . \ldots \ldots$

A. Formation OF CONTRACT A/CONTRACT B . . . . . . . . . 500

B. IMPLIED OBLIGATION TO ACCEPT ONLY COMPLIANT BIDS . . . . . 500

C. Duty to Negotiate Fairly and in Good Faith . . . . . . . . . . 502

D. APPLiCATION IN UPSTREAM OiL, GAS, AND

OILSANDS TRANSACTIONS . . . . . . . . . . . . . . . . . . . . 505

III. CoMPETITIVE BIDDING PROCESS . . . . . . . . . . . . . . . . . . . . 505

A. Traditional Tender Process vs. Requests for

EXPRESSIONS OF INTEREST, REQUESTS FOR QUOTATIONS, REQUESTS FOR PROPOSALS, AND OTHER COMPETITIVE BID

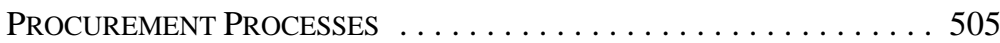

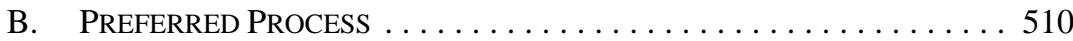

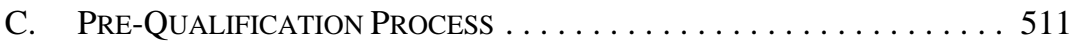

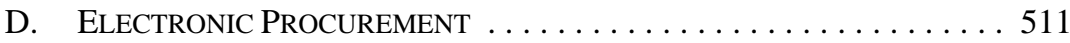

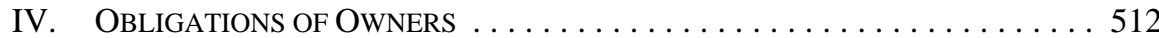

* $\quad$ Partner, Osler, Hoskin \& Harcourt LLP, Calgary, Alberta.

*** Partner, Osler, Hoskin \& Harcourt LLP, Calgary, Alberta.

**** $\quad$ Legal Counsel, Chevron Canada, Calgary, Alberta.

***** Legal Counsel, Chevron Canada, Calgary, Alberta. The authors wish to extend a special thanks to Raj Dhaliwal and Cheryl Kelly of Osler, Hoskin \& Harcourt LLP for their extensive assistance with the preparation of this article. 
A. Following the Terms of REFERENCE $\ldots \ldots \ldots \ldots \ldots \ldots 12$

B. Using a SHORT List Process . . . . . . . . . . . . . . . . . . . . . 512

C. ACCEPTING A NON-COMPLIANT BID . . . . . . . . . . . . . . . 513

D. Negotiating the Terms of Contract B . . . . . . . . . . . . . . 515

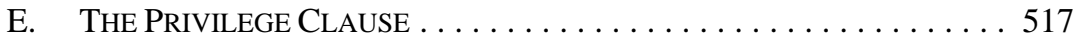

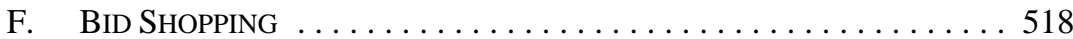

G. GUIDELINES FOR THE TENDER PROCESS AND

DRAFTING OF TENDER DOCUMENTS . . . . . . . . . . . 519

V. OBLIGATIONS OF BIDDERS . . . . . . . . . . . . . . . . . . . . . . 521

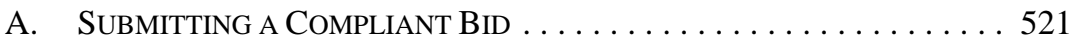

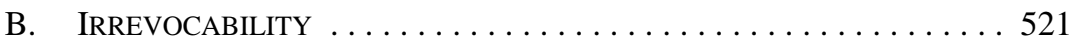

C. Correcting TENDER DEFICIENCIES AND ERRORS $\ldots \ldots \ldots \ldots \ldots 521$

D. SUBCONTRACTOR/SUB-CONSULTANT WORK . . . . . . . . . . . . 522

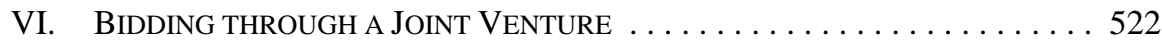

VII. THE JOINT VENTURE AS OWNER . . . . . . . . . . . . . . . . . . . . . . . . . 523

VIII. COMPANIES' CREDITORS ARRANGEMENT ACT IMPLICATIONS

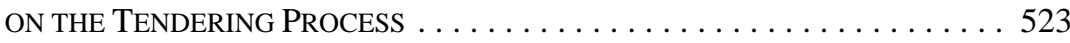

IX. DAMAGES AND LimitATION OF LIABILITY . . . . . . . . . . . . . . . . . . 524

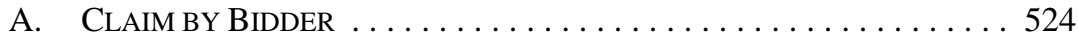

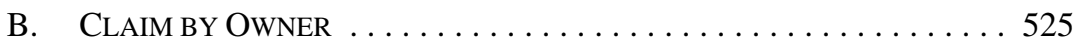

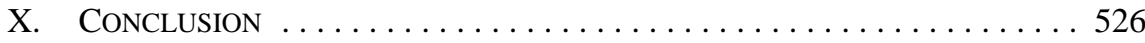

\section{INTRODUCTION}

Since the seminal case of Ron Engineering, ${ }^{1}$ establishing the formation of Contract $\mathrm{A} /$ Contract $\mathrm{B}$, the jurisprudence has refined the respective rights and obligations of owners and bidders in the bidding process. While the courts have implied terms in Contract A, owners can carefully control the imposition of such implied duties by including appropriate language in their tender documents.

Given the specialized and capital intensive nature of upstream oil, gas, and oilsands projects, producers must adopt competitive procurement strategies to be able to secure specialized goods and services from the most qualified contractors, in the most cost-effective manner and within the timeline afforded by their scheduling needs. When engaging service providers in their selection processes, producers must undertake such processes fairly and in good faith, in accordance with the terms of the bid documents and generally in line with the general expectations of the parties to the process.

Competition has replaced negotiation in many tendering processes as the basis on which contractual relations are formed, particularly for medium and large-scale oil, gas, and oilsands projects. This applies whether the process is structured as a request for expression of interest, request for quotation, request for proposal, or as a formal tender process. An owner must weigh the main differences between such approaches, including the binding versus non-binding nature thereof against its desire to maintain flexibility in deciding which approach to use for its project. An owner will be entitled, on clear language, to use a short 
list process, to accept a non-compliant bid, to assess and accept a bid in its sole and absolute discretion, and to cancel or amend the tender process at any time and in any manner.

Bidders, on the other hand, must carefully comply with bid instructions and submit a compliant bid. Errors in a bid submission or other deviations from the terms of Contract A may lead to rejection of the bid. Indeed, the courts have held that it is an implied term of Contract A that an owner may only accept compliant bids, and that any right of an owner to waive non-compliance only applies to deviations that are an informality or minor or administrative in nature.

After assessment of the bids, the owner will typically award the work or project to the successful tenderer and the parties will enter into Contract B. Negotiation of the terms of Contract B may occur before, during, or after award to the successful bidder, depending on the tender process followed and the terms of the bid documents. During bidding and negotiation, a "battle of the forms" may arise when a contractor's bid or acceptance does not align exactly with the owner's tender, request documents, or standard form agreement. This situation can be avoided, or at least minimized, if the owner includes, to the largest extent possible, the proposed terms of Contract B in its tender documents and requires bidders to submit their comments on such proposed terms as part of the bid submission.

An owner may be held liable to pay a bidder damages for breaching the terms of Contract A, subject to any exclusion clauses that may be available to an owner. Where a bidder breaches Contract A, an owner may claim against any deposit, bid bond, or other security provided by a bidder in conjunction with its bid, subject to any defences that may be available to a bidder.

The objective of this article is to provide owners, and in particular oil, gas, and oilsands producers, with an overview of various procurement processes and specific suggestions on how owners can structure such processes, draft tender documents to meet their goals, and avoid the liability that often arises out of the tendering process. In particular, the scale and cost of oil, gas, and oilsands projects, as well as the change in market conditions, raise new issues in the procurement context that owners should consider. Obligations of bidders in the procurement process are also reviewed and the article concludes with a discussion of joint ventures, the Companies' Creditors Arrangement Act ${ }^{2}$ process, and project liability, as such topics may apply in the tendering process.

\section{General PRinciples}

There are three governing principles that the Supreme Court of Canada has identified in respect of the tendering process in Canada. Although the details relating to such principles have been refined over the years, the basic concepts are still applicable today and are set out below for convenience. 


\section{A. Formation OF CONTRACT A/CONTRACT B}

In Ron Engineering, the Supreme Court of Canada established the legal framework governing the tendering process. Upon submission of a compliant bid in response to a tender call, a contract, referred to as "Contract A," is formed between the owner and the bidder. The express terms of Contract A are set out in the tender documents upon which bids are submitted. The terms of Contract A provide the rules pertaining to the submission of bids and typically mandate that the selected bidder enter into the more formal contract for the work, known as "Contract B."

A core theme in Ron Engineering and repeatedly referred to in later jurisprudence is the need to maintain the integrity of the tendering process and thereby preserve the reasonable expectations of the parties participating in it. The existence of Contract A precludes a bidder from otherwise revoking a bid that is intended to be irrevocable and requires such bidder to enter into Contract B if such bidder is the successful bidder.

\section{B. IMPLIED OBLIGATION TO ACCEPT ONLY COMPLIANT BIDS}

In the subsequent decision of M.J.B. Enterprises, ${ }^{3}$ the Supreme Court of Canada expressly rejected the view that Ron Engineering stood for the proposition that Contract A comes into existence in all cases upon submission of a tender. Instead, the Supreme Court of Canada stated that the revocability of Contract A must be determined by reference to the terms and conditions of the tender call and the related documents upon which a tender is submitted. ${ }^{4}$

The key issue in M.J.B. Enterprises was whether the inclusion of a privilege clause, "The lowest or any tender shall not necessarily be accepted," in tender documents permitted the owner to disregard the lowest bid in favour of any other bid, including a non-compliant one. In that case, the lowest bid had been accepted notwithstanding that such bid did not conform with the tender requirements. The bidders were to submit a per lineal metre price for construction of the water system regardless of the type of fill that would be used for backfilling the trenches for the pipes. The successful bidder submitted a bid with a note giving a per lineal metre price based on a certain type of fill and stated that an additional cost per metre would apply if a different type of fill was required. The bidder with the second lowest bid brought the action on the basis that this note should have invalidated the successful bidder's tender as it constituted a qualification. Justice Iacobucci noted that the rationale for the tendering process is to replace negotiation with competition and stated that it was an implied term in Contract A that the owner would only accept compliant bids. A privilege clause does give the company the choice of not accepting the lowest bid, but the tender must still be complete and compliant. One has to take risks in making a tender, and no one would do this if the company could circumscribe this process and accept a noncompliant bid. It is reasonable to infer that the respondent would only take valid tenders. ${ }^{5}$ Justice Iacobucci found that the inclusion of a privilege clause imposed an obligation on an 
owner to accept only a compliant bid rather than an obligation to accept only the lowest compliant bid.

The issue of compliance was addressed in Graham Industrial Services Ltd. v. Greater Vancouver Water District. ${ }^{6}$ The bidder petitioned the British Columbia Court of Appeal for declarations that the tender it had submitted to the owner failed to comply with the Instructions to Tenderers and consequently no Contract A was formed and the tender was incapable of acceptance by the owner. The owner sought to rely on a discretion clause in the Instructions to Tenderers that permitted it to deem any defects to be non-material. The British Columbia Supreme Court found that failure to provide certain technical information deemed the bid non-compliant. The British Columbia Court of Appeal upheld the decision of the Supreme Court and found that a discretion clause cannot be relied upon to render a materially non-compliant tender capable of acceptance. It reasoned that Contract A cannot come into existence unless the tender is substantially compliant with the call for tenders. It is the submission of a compliant tender that establishes the legal relationship (Contract A) between the parties and the submission of a materially non-compliant bid is, in essence, a counteroffer. The British Columbia Court of Appeal concluded that the test of whether a defect in a tender is material is an objective test. This case is unusual as it allowed a contractor to use its own defective tender as a shield to prevent Contract A from coming into existence.

In Silex Restorations Ltd. v. Strata Plan VR 2096, ${ }^{7}$ a bid was found to be materially noncompliant when a bidder provided a 60-day bid bond rather than a 90-day bid bond as required by the invitation to tender documents. The British Columbia Court of Appeal stated that, "[i]n considering materiality, the rationale for the tendering process, which is to effect fair competition, and the risk of action by compliant bidders must be considered." ${ }^{8}$ As the cost of securing a bid bond is proportionate to its duration, a bidder with the shorter security will incur lower costs, giving it an advantage. While the British Columbia Court of Appeal stated that the test of materiality is objective, the behaviour of the parties was considered indicative of the significance of the requirement for a 90-day bid bond to a reasonable person.

In Transit Glass \& Aluminum Ltd. v. Sakto Corp. ${ }^{9}$ a bid was found to be substantially or materially non-compliant due to a failure to provide the owner with information and drawings that had been clearly stipulated in the tender documents. The Ontario Superior Court of Justice emphasized that the issue of whether a bid is substantially compliant must be determined objectively and at the time of the opening of the tender bids.

The call for tenders in Jarlian Construction Inc. v. Waterloo (City of) ${ }^{10}$ provided that the bid price was not to include the price for any alternative items. Bidder A was the lowest bidder. Bidder $\mathrm{B}$ included the price for an alternative item in its bid price. The owner accepted Bidder B's bid as the lowest bid after reducing its bid price by the amount of the alternative item. It was held that Bidder B's bid was non-compliant for failure to comply with 
the terms of the tender documents and that, by accepting Bidder B's bid, the owner was in breach of its implied obligation to accept only a compliant bid. Further, it was held that by altering Bidder B's price, the owner amended the bid and breached its duty to treat all bidders fairly and equally. ${ }^{11}$

In Structures GB Itée c. Rimouski (Ville de), ${ }^{12}$ a bidder claimed damages from the owner when its tender was rejected on the ground that the bid bond provided was in an amount less than that required by the tendering documents. The Superior Court of Quebec held that the omission by a general contractor to provide the full amount of suretyship was a minor and secondary default that had no consequence whatsoever on the bidding price. As to what constitutes a minor or secondary default, the Superior Court of Quebec stated that the omission or irregularity in the tender must not have an effect on the price or on an essential consideration stipulated in the tendering documents. ${ }^{13}$

\section{DUTY TO NEgotiate FAIRLY AND IN GOOD FAITH}

There has been much legal consideration of this duty and there are clear guidelines on how this duty applies. In Martel, ${ }^{14}$ Iacobucci J. concluded that a provision to treat all bidders equally and fairly is implied in Contract A. He further concluded that a privilege clause reserving the right not to accept the lowest or any bid does not exclude the obligation to treat all bidders fairly.

As noted in Chinook ${ }^{15}$ and Power Agencies Co. v. Newfoundland Hospital and Nursing Home Assoc., ${ }^{16}$ the owner is held to a duty to ensure that all bidders are treated equally so as not to give one an unfair advantage over another.

In Martselos Services, ${ }^{17}$ the Northwest Territories Court of Appeal held that in order to protect the integrity of the bidding system, there should be "a duty to treat all bidders equally but still with due regard for the contractual terms incorporated into the tender call."”

In George Wimpey, ${ }^{19}$ the Ontario Court, General Division, found that owners and tenderers have reciprocal obligations that arise from the contract created by submission of the bid and concluded that owners are obligated to treat all bidders fairly and in good faith, and are in breach of that duty if contracts are awarded on the basis of considerations that are extraneous to those identified in the tender documents.

Ibid. at para. 35 .

2008 QCCS 1923, [2008] R.D.I. 528.

Ibid. at para. 38 .

Martel Building Ltd. v. Canada, 2000 SCC 60, [2000] 2 S.C.R. 860 [Martel].

Chinook Aggregates Ltd. v. Abbotsford (Municipal District of) (1987), 28 C.L.R. 290 (B.C. Co. Ct.), aff'd (1989), 40 B.C.L.R. (2d) 345 (C.A.) [Chinook].

(1991), 90 Nfld. \& P.E.I.R. 64 (Nfld. S.C. (T.D.)).

Martselos Services Ltd. v. Arctic College, [1994] N.W.T.R. 36 (C.A.) [Martselos Services].

Ibid. at para. 20.

George Wimpey Canada Ltd. v. Hamilton-Wentworth (Regional Municipality) (1997), 34 C.L.R. (2d) 123 (Ont. Ct. J. (Gen. Div.)) [George Wimpey]. 
In Sound Contracting, ${ }^{20}$ notwithstanding that Sound Contracting was the lowest bidder, the City awarded the contract to the second lowest bidder as the City believed that this would result in the best overall value. The request for tender provided that the City reserved the right to reject any or all tenders and that the lowest tender would not necessarily be accepted. The British Columbia Court of Appeal concluded that the privilege clause in the request for tenders released the City from the obligation to award the work to the lowest bidder where there were valid, objective reasons for concluding that better value may be obtained by accepting a higher bid, as long as the essential requirements of objective fairness and good faith had been met by the owner.

In Acme Building and Construction Ltd. v. Newcastle (Town of), ${ }^{21}$ Contract B was awarded to the second lowest bidder because it proposed to complete the project in a shorter period than the lowest bid, resulting in large cost savings and less business disruption to the owner. All tendering contractors had been asked to stipulate a completion date in their bids. The Ontario Court of Appeal held that the owner could accept a bid other than the lowest bid as the instructions to tenderers specified that the owner had the right not to accept the lowest or any other tender.

The courts appear generally reluctant to second-guess the exercise of an owner's good faith discretion to reject a tender, even if it is the lowest bid. ${ }^{22}$

An owner has been found to be in breach of its duty of good faith by refusing to award Contract $\mathrm{B}$ to the lowest bidder in a situation where agreement was reached on price and material terms forming Contract A but the owner subsequently added a new criterion or precondition to the creation of Contract B, which the Ontario Superior Court found exceeded the good faith use of discretion. ${ }^{23}$

Similarly, an owner was found to have breached its duty of good faith when it gave preferential treatment to a bidder by allowing it to correct its tender form after the close of tenders to clarify uncertainty in price. The British Columbia Court of Appeal found that a privilege clause in the tender documents, which stated that irregularities contained in tenders could be considered informal, did not provide the owner with the discretion to permit correction of the price discrepancy and was not a good faith exercise of discretion. ${ }^{24}$

In Port Hawkesbury, ${ }^{25}$ the owner received only one bid in response to its tendering process and the bid submitted exceeded the owner's budget. The owner proceeded to enter into negotiations with a third party for the work without rejecting the bid and without informing the bidder of such negotiations. The Nova Scotia Court of Appeal held that the bidder was at a distinct disadvantage as a result of the owner failing to renegotiate the contract with it

Sound Contracting Ltd. v. Nanaimo (City of), 2000 BCCA 312, 74 B.C.L.R. (3d) 239 [Sound Contracting].

(1992), 2 C.L.R. (2d) 308 (Ont. C.A.).

See e.g. B.A. Blacktop Kamloops v. British Columbia (Ministry of Transportation and Highways) (1996), 24 B.C.L.R. (3d) 149 (S.C.); Sound Contracting, supra note 20.

Maple Engineering \& Construction Canada Ltd. v. 1373988 Ontario Inc. (2004), 38 C.L.R. (3d) 183 (Ont. Sup. Ct. J.).

Vachon Construction Ltd. v. Cariboo (Regional District) (1996), 24 B.C.L.R. (3d) 379 (C.A.) [Vachon] . Port Hawkesbury (Town of) v. Borcherdt Concrete Products Ltd., 2008 NSCA 17, 262 N.S.R. (2d) 163 [Port Hawkesbury]. 
and failing to allow it to take part in discussions between the owner and the third party. It was held that the owner breached its duty to ensure that the bidder was treated fairly and equally.

Allowing a modification of a tender after tender closing without giving the same opportunity to other bidders was also held to be a breach of fairness owed to bidders in 3051226 Canada Inc. c. Aeroport de Montreal. ${ }^{26}$ The Quebec Court of Appeal emphasized that it is established law that owners have an obligation to act fairly towards all bidders and to treat them equally, in order to protect the integrity of the bidding system. The Quebec Court of Appeal held that an exoneration clause in the tender documents that deprived bidders of having recourse of any nature against the owner did not release the owner from an action for damages by the bidders relating to the owner's breach of the essential obligation to treat all bidders fairly. ${ }^{27}$

In The Windsor Utilities Commission v. Oscar Construction Company Ltd., ${ }^{28}$ the owner accepted the lowest tender submitted. The tender documents stipulated a completion date of March 1999. Due to delays, the owner sought to extend the completion date of the bidder's work to May 1999 without additional compensation. The bidder refused to perform the work according to the new schedule without additional compensation. The owner then awarded the work to the second lowest bidder. The Ontario Supreme Court of Justice held that when the owner failed to provide the lowest bidder with a contract containing the terms of the accepted bid, the owner breached its agreement with the bidder and such breach entitled the bidder to damages for its loss of profits.

In Force Construction Ltd. v. Nova Scotia (Attorney General), ${ }^{29}$ the bid instructions specified that a certain type of window had to be used when performing the project. Bidder A named Window World as its supplier in its bid package. After bids had closed, concerns as to Bidder A's ability to perform and, in particular, concerns regarding availability of supply from Window World, were raised. The owner requested Bidder A to provide written confirmation by a specified date from Window World confirming that it could supply the required type of window. When Bidder A was only able to secure oral assurances from Window World by the specified date, the owner rejected the bid of Bidder A and awarded the contract to the second lowest bidder. The instructions to bidders stated that bidders "shall be evaluated on contract price" and also included a privilege clause giving the owner "the right to accept or reject any or all offers or to accept any offer deemed most satisfactory" and the right to "waive any informality in any or all bids." ${ }^{30}$ The Nova Scotia Supreme Court held that Contract A arose when Bidder A submitted its compliant bid, as Bidder A agreed to provide the specified windows and maintained this intention throughout the bidding process. It further held that the owner breached the terms of Contract A by requiring Bidder A to provide written confirmation from its window supplier, a condition the other bidder was not subject to. The bid documents did not contemplate that the owner could impose such a requirement on a single bidder nor did it permit a contract to be awarded on the basis of an

2008 QCCA 722, [2008] R.J.Q. 872, leave to appeal to S.C.C. refused, 32687 (9 October 2008).

Ibid. at para. 54 .

(9 August 2007), Windsor 99-GD-45981 (Ont. Sup. Ct. J.).

2008 NSSC 327, 270 N.S.R. (2d) 292.

Ibid. at para. 36 . 
undisclosed term. In addition, the deadline imposed by the owner for obtaining confirmation from the window supplier was unreasonable and amounted to a breach of the owner's duty to deal with Bidder A in good faith. In the result, the Nova Scotia Supreme Court found that Bidder A was not treated fairly and equally and awarded damages in excess of $\$ 200,000$. Therefore, if an owner is concerned about the financial stability of a subcontractor or the availability of a product to be supplied by a sub-contractor that is material to the timely execution of the project, it should request evidence of the same from all bidders at the time of bid submission.

\section{ApPlication in UPSTREAM OIL, GAS, AND OILSANDS TRANSACTIONS}

The basic duties initially outlined by the Supreme Court of Canada in Ron Engineering and further developed and confirmed in subsequent case law must be considered by all producers when structuring and developing tendering and requests for proposals (RFP), requests for quotations (RFQ), and other processes for construction of upstream projects in Canada. In order to secure the specialized goods and services required for their projects, owners and producers must develop competitive procurement strategies and processes to meet their objectives, which will include selecting the most qualified contractors and contracting for such work in the most cost-effective manner and in line with their scheduling requirements. Accordingly, when engaging service providers in their selection processes, producers will be bound to engage in such processes fairly and in good faith and generally in line with the expectations of the parties to the process. The nature of the process undertaken by an owner is also critical in allocating responsibility and liability, as the following analysis illustrates.

\section{Competitive Bidding Process}

Competition is a reality of most contractual relations in oil, gas, and oilsands tendering processes, whether relating to facility construction, procurement of oil field goods or services, or the sale of a company or its assets. Competition has historically been fierce, whether the process is structured as a request for expression of interest (RFEI), RFQ, RFP, or a formal tender process. The following analysis explains the differences among such approaches.

\section{A. Traditional Tender Process vs. Requests for EXPRESSIONS OF INTEREST, REQUESTS FOR QUOTATIONS, REQUests for Proposals, AND OTHER CoMPETITIVE BID Procurement Processes}

The different approaches to procurement exist on a continuum. At one end, the formal tendering process provides parties with contractual protections but also imposes corresponding obligations and duties. At the other end, RFEIs, RFQs, and RFPs provide no contractual protections nor corresponding obligations and duties, enabling either party to walk away from negotiations at any point prior to a binding agreement being reached. As the discussion below illustrates, it is becoming common for owners to combine elements of the 
various procurement processes in order to design a process to achieve their particular objectives. This is commonly referred to as a "hybrid procurement process."

\section{Traditional Tender Process}

The traditional tendering process is characterized by well-defined instructions to bidders setting out the terms and conditions governing the competitive process and requiring the irrevocability of bids. Subject to any enforceable rights of an owner under a privilege clause, non-compliant bids will be rejected. Security for the bid in the form of a bid bond, deposit, letter of credit, or guarantee may be required. Upon submission of a bid, Contract A arises between the owner and bidder creating binding contractual relations.

A formal tender call can provide certainty and rigour to the procurement process. By structuring a tender so that bidders must submit an irrevocable bid with an accompanying deposit or other security, an owner has greater assurance that the bidder is contractually bound to enter into Contract B and perform the work required by the owner, failing which the bidder forfeits its deposit or security.

A formal tender process is most effective when the owner requires certainty of the desired end product for its project, both in terms of the scope of work and the schedule of performance of the work. This can be particularly important for large or multi-phase projects in the oil, gas, and oilsands industries given that there is often a limited supply of particular goods and services and there are often many owners and producers competing for the same services. This process is designed to be efficient as bidders are instructed in the invitation for tenders to submit bids to address a defined scope of work with specified outcomes or deliverables. In addition, Contract B is substantially settled in most tender calls subject to minor negotiations. Accordingly, an owner can be satisfied that Contract B will contain all of the terms and conditions it requires to achieve its goals for its project. The owner is thus able to achieve certainty around the terms of its project or work, including who will perform the work, when the work will be completed, what the cost will be, and what other terms and conditions will apply to the performance of the project or work.

The primary disadvantage of a formal tender process is that owners limit their flexibility to substantially alter the terms of Contract B or to select non-compliant bids. In addition, entering into a Contract A relationship with bidders creates obligations of good faith and fairness and can provide bidders a basis to advance claims against an owner if the tender process is not administered according to the invitation for tenders or is carried out in a manner that is unfair to bidders.

In addition to express terms included in the call for tenders, there is an implied duty of good faith between parties involved in a formal tendering process. In order to discharge this duty, an owner must treat all bidders fairly and equally. Allegations of breach of this implied duty are quite common. As a result, an owner should structure and administer its tendering process in a manner that will withstand judicial scrutiny. To limit or successfully defend the claim of a bidder that the owner has breached such implied duty, an owner must strive to maintain the integrity of the tendering process and to preserve the reasonable expectations of parties who engage in it. 
It should be noted, however, that it is always possible that Contract A is not formed between an owner and a bidder upon the submission of a bid, or that Contract $\mathrm{A}$ is formed but the irrevocability of the bid is not one of its terms, in which case the process will be deemed to be something other than a formal tender process. ${ }^{31}$

\section{REQUESTS FOR EXPRESSIONS OF INTEREST, REQUESTS FOR QUOTATIONS, AND REQUESTS FOR PROPOSALS}

\section{a. Requests for Expressions of Interest}

An RFEI process is commonly used for medium and large-scale projects as part of a multistage procurement process and will precede a formal tender or RFP process. The RFEI process allows an owner to engage interested parties and gather information to assist in designing and developing the tender process for the potential project. For medium and largescale projects, an RFEI process can be of particular importance to assist the owner in planning and scheduling the procurement piece of the overall project and estimating the cost of the different scopes of work and the project in its entirety.

\section{b. Requests for Quotations}

An RFQ process is commonly used when discussion or negotiation with the bidder is not required. This could arise in a situation where there is a defined work scope and price is the main or only factor in determining who will be selected to perform the work. An RFQ process is primarily used prior to a formal tender process or RFP process in order for an owner to get a general indication of the cost of the work. An owner will often issue RFQs for the various goods, equipment, materials, and fabricated components required for a medium or large-scale oil, gas, or oilsands project in order to assist the owner in determining the potential cost and delivery schedule for such items and developing the overall project budget and schedule.

\section{c. Requests for Proposals}

An RFP process is a non-binding selection process whereby the owner requests proposals to be submitted based on a set of loosely defined parameters. The scope of work may not be well-defined or the RFP process may permit the proponents to define parts of the scope or deliverables in the proposal. The criteria used to evaluate proposals may not be easily ascertainable. This may allow an owner to select non-compliant offers and select any proposal submitted if there is little or no selection criteria specified. A proposed form of contract may be attached, but the terms will be open to negotiation. No security will be required at the time the proposal is submitted. The owner will evaluate the submissions received and will select the proposal that best meets the owner's objectives. Once a proponent is selected, the owner will enter into a period of non-binding negotiations with respect to the price, scope of work, or contract terms and conditions with a view to reaching an agreement with such proponent. 
The fundamental difference between an RFP and a tender process is that there is no intention to create contractual relations at the time of proposal submission (that is, no Contract A arises). The result is a flexible process and one that is often used where an owner knows the intended outcome but is unsure how to proceed in its construction. The RFP process is collaborative in nature allowing owners to work with parties submitting proposals in order to better define the owner's needs. This allows for ingenuity, creativity, and value engineering in submitted proposals as proponents are not regimented in the form of their submitted proposal. This process encourages negotiation between parties, in particular with respect to pricing and technical aspects of the project.

Like an RFEI and RFQ process, an RFP process may be used as a preceding phase to a formal tender process, allowing an owner to secure non-binding proposals as to price and schedule before proceeding with a binding process. This can assist an owner in developing its overall project schedule and budget, which is of particular importance for the planning and development of medium and large-scale projects in the oil, gas, and oilsands industries where specialized goods and services are required and there may be a limited number of contractors providing goods and services that are in large demand.

A primary disadvantage of the RFP process is that it is usually more complex and can take longer than a traditional tender process as the main terms and conditions of Contract $\mathrm{B}$ are subject to negotiation. This is especially problematic if the owner has a desired completion date. An RFP process can introduce completion risk as the proponents are free to walk away at any point in negotiations until a definitive agreement is entered into. RFPs also have the potential to dissuade parties from submitting proposals as they may be hesitant to incur costs and invest the time and resources required for the preparation of a proposal given the uncertainty in the selection process. This can be a particularly important consideration for large or multi-phase oil, gas, or oilsands projects as the time and resources required to prepare a proposal can be significant.

Moreover, as RFP processes allow for more subjectivity in the evaluation process, this may be perceived negatively by a potential purchaser or the court in a CCAA proceeding when approving the contract.

\section{d. Duty in the Request for Proposal Process}

There is conflicting case law respecting the duty owed between an owner and a proponent in an RFP process. Some courts have held that there is no requirement to negotiate in good faith as this is repugnant to the adversarial nature of contract negotiation between parties. ${ }^{32}$ In other cases, courts have suggested that a lesser duty of fairness exists between the parties in an RFP process. ${ }^{33}$ It is, however, clear that any duty of fairness that applies is substantially less than what is owed between parties in a formal tender process. Consequently, both owners and proponents are typically free to withdraw from negotiations with relative impunity. 


\section{e. Risk of Classification of Request for Proposal as a Call for Tenders}

An owner who wishes to employ an RFP process must carefully structure the language in the RFP documentation and the procedural elements of the process so as to not create unintended contractual obligations upon the submission of proposals. Traditionally, RFPs have been considered to be outside the ambit of tendering law. However, if an RFP has the characteristics of a tender (that is, formality of procurement process, complexity of submitted proposals, and limited extent of negotiation), there is a risk that the courts may impose Contract A obligations that the owner may not have intended. ${ }^{34}$

Referring to a procurement document as an RFP is not determinative of the duties and obligations that may apply to the parties. In Tercon, the British Columbia Supreme Court listed a number of factors that are indicia of a tender process giving rise to Contract $\mathrm{A}$ obligations, including: irrevocability of proposals, formality of the procurement process, whether there is a deadline for submissions and performance of work, whether a security deposit is required, how specific the conditions of submitted proposals are, whether the selected proponent is obligated to enter a contract, and whether there were specific conditions not open to negotiation. ${ }^{35}$ Owners often insert language specifying whether the process is intended to be binding or not. However, simply calling a document a "request for proposals" or a "request for tenders," or including such language is not determinative of whether contractual duties and obligations arise from the process. The court will look to the precise language in the instructions and documentation provided to proponents and the substance of the request in order to determine whether the parties intended to enter into a contractual relationship (that is, Contract A).

\section{f. Avoiding Classification as a Call for Tenders}

To create an RFP process, the Tercon factors should be carefully contemplated and the request documentation must be clear that the owner has no binding legal obligations to parties submitting proposals. Further, the request should state that parties submitting proposals are willing to negotiate and are not contractually bound until the parties have duly executed a written agreement relating to an approved proposal.

Additionally, an owner should not include a final form of Contract B in the RFP package. Instead, only the heads of agreement or essential elements of the contract should be included as guidance to those submitting proposals. The request may also permit submission of alternative proposals and allow for negotiations respecting technical matters as well as price. Ultimately, the structure of the RFP must be considerably less formalized than a tender call to avoid categorization as a call for tenders and the imposition of the Contract A duties and obligations on the parties. 


\section{B. PREFERRED PRocess}

An owner should consider the main differences between the processes outlined above, including the binding versus non-binding nature and an owner's ability to maintain flexibility in the process, and draft its instructions and documents to meet its key objectives. Where an owner is looking for a process that will provide detailed bids to ensure all project parameters are met and attain certainty of bidder while preserving the maximum amount of flexibility in the tender process, it is recommended that a binding tender process be used and express Contract A language be inserted in the tender documents, along with a detailed procedural framework that clearly describes the process and outlines the rights and obligations of the parties involved, with provision for as much procedural flexibility as possible in the assessment, consideration, and selection of the successful bidder.

An RFP process should be used where an owner seeks to obtain non-binding proposals that will form the basis of negotiations leading to a binding contract, but which do not require the chosen bidder to enter into Contract B. If an RFP process is implemented, an owner will have more flexibility with respect to negotiating the terms of the binding contract but there are more risks and greater uncertainty as the process is not binding until Contract B is signed and a proponent can withdraw from the process without forfeiting any deposit or other security. In addition, if the RFP process contains characteristics of a tender call, there is a risk that a court could find that the submission of proposals created Contract A obligations and duties between the parties notwithstanding the absence of such intention.

An owner may also wish to consider a multi-stage procurement process where an RFQ or RFEI process precedes the tender or RFP process. Where the owner has a clearly defined project or work scope and price is the dominant factor in determining who will perform the work, an RFQ process may be used to provide the owner with a general indication of the cost of the work in the current market. On the other hand, where an owner wishes to identify potential projects to complete a large or medium scale project and gather information on project viability and status for consideration in a subsequent procurement process, an RFEI process may be useful as an initial step in the procurement process.

Generally, the scale and cost of projects in the oil, gas, and oilsands industries will necessitate multi-stage procurement processes. The use of an RFEI, RFQ, or RFP process, or a combination thereof, to precede a tender or RFP process is beneficial to oil, gas, and oilsands producers looking to plan, develop, coordinate, and manage the costs of medium and large-scale projects.

Also, oil, gas, and oilsands producers will generally want to manage large projects in phases or segments to ensure a phased and measured approach to development. The Horizon Oil Sands Project in northeastern Alberta represented a new approach to oilsands mega project development. ${ }^{36}$ Extensive front-end engineering and design before proceeding with the construction phase reduced the risk of scope changes, thereby enabling lump sum engineering procurement construction bids. Fixed price construction costs allowed Canadian Natural Resources Ltd. to have greater control over its mega project. 


\section{Pre-Qualification Process}

A pre-qualification process can be employed by the owners at the very outset of a procurement process and prior to the issuance of any tender documents to pre-qualify parties that will be invited to participate in the procurement process. An owner should consider a pre-qualification process if the owner wants bidders or proponents to be able to comply with particular standards, possess certain qualifications, or demonstrate certain skills, experience, and resources to carry out the project or provide the goods or services required.

Given the specialized nature of the work required for oil, gas, and oilsands projects, a prequalification process is often used as a first step in the procurement process to confirm that the contractors that will be considered have the relevant experience, proper safety certifications and procedures, and the necessary resources to perform the work. The recent change in economic conditions of global markets and commodity prices have led to delay and even cancellation of many oilsands projects. While this means owners will have access to a greater supply of the specialized goods and services required for their projects, it also means owners will have to exercise greater caution in their contractor selection processes. As less projects and work in the oil, gas, and oilsands industries become a reality, unqualified contractors or contractors who do not have the necessary resources to complete the project (because they've laid off workers to contain costs in the current economy) may submit proposals in an attempt to obtain any available work.

An advantage of the pre-qualification process is that it allows an owner to conduct an evaluation process outside the confines of Contract A and well in advance of any corresponding obligations and duties arising. The submission of credentials by bidders does not create contractual obligations between the parties; therefore, an owner is free to consider information about prospective bidders or proponents during pre-qualification that might otherwise be prohibited or restricted if the evaluation took place within the context of Contract A.

The implementation of a pre-qualification procedure, however, may later fetter an owner's discretion in relying on a privilege clause. In Ed. Brunet, ${ }^{37}$ the plaintiff bidder successfully argued that once a pre-qualification process was complete and possible tenderers chosen, the owner could not reconsider any of the criteria in the pre-qualification process in awarding Contract B. As a result, including a pre-qualification process as part of a procurement process may limit the flexibility granted to owners under a privilege clause included in the bid documents.

\section{Electronic Procurement}

Some owners may choose to post their invitation to bid and bid documents on a web site. In Alberta, the Electronic Transactions Act ${ }^{38}$ applies to electronic procurement processes. With similar legislation in each Canadian province and territory, legal uncertainty around 
electronic communications is removed. The Act ensures that electronic transactions have the same validity and enforceability as traditional, paper-based transactions. Specifically, s. 27 of the Act confirms that:

[A]n offer, the acceptance of an offer or any other matter that is material to the formation or operation of a contract may be expressed

(a) by means of information or a record in electronic form, or

(b) by an act that is intended to result in electronic communication, such as

(i) touching or clicking on an appropriate icon or other place on a computer screen. ${ }^{39}$

\section{OBLigations OF OWNERS}

\section{A. Following THE TERMS OF REFERENCE}

An owner may create a relatively flexible procedural framework for its tender process, provided all bidders are treated fairly and the terms of its bidding documents are clearly provided and adhered to. By inserting clear language in its bid documents, an owner is entitled to use a short list process, to accept a non-compliant bid, to negotiate the terms of Contract B, to assess and accept a bid in its sole and absolute discretion, and to cancel or amend the tender process at any time and in any manner. Given the large scale and cost of many oil, gas, and oilsands projects, it is particularly important for producers to carefully follow the terms of reference in their bid documents and engage in the procurement process fairly and in good faith in order to avoid project delays due to disputes with bidders.

\section{B. USING A SHORT List Process}

An owner may wish to invite a large number of tenderers to bid and then select and negotiate with a short list of such bidders before choosing the successful bidder. In order to achieve this result, the following language could be incorporated into the call for tenders:

\footnotetext{
A large number of tenders will be invited to bid in the initial tender process. The Owner shall determine at its sole and absolute discretion which bids, if any, shall be accepted or which bidders will be invited as short listed bidders to negotiate with the Owner. The Owner reserves the right to enter into negotiations with the short listed bidders, separately or contemporaneously, and identify a successful bidder as a result of those negotiations. At the Owner's sole and absolute discretion the short listing process may occur in multiple stages. In addition, the Owner reserves the right, at any time, following the preparation of the list of short listed bidders, to request that any one or more bidders clarify its bid and such bidders shall submit responses to such a request within five (5) days following the date of the receipt of such request, or within such shorter time as the Owner may require. Without limiting the generality of the foregoing, the Owner may request clarification where any one or more bidders' intent is unclear (including, without limitation, where there is an irregularity or omission in the information or documents provided by the bidder in their bid) and may request the clarification. The Owner may, in its sole and absolute discretion, choose to meet with one, some, or all of the bidders to clarify any aspects of their bids. The Owner may require bidders to submit
} 
supplementary documents clarifying any matters contained in their bids or the Owner may prepare a written interpretation of any aspect of a bid (including, without limitation, meeting minutes) and seek the respective bidder's acknowledgement of that interpretation. ${ }^{40}$

However, the use of a multiple stage tender process may raise issues as to whether the process is binding during all stages of the process. Some case law suggests that a two-step process can inject risk into a tender process by interfering with the goal of creating a clear set of binding obligations on bidders. ${ }^{41}$ Additionally, the use of a multiple stage tender process may introduce a greater level of uncertainty and complexity into the process, which may potentially increase the risk of procedural fairness claims from disgruntled bidders.

To achieve procedural fairness where a short list process is used, owners should consider and utilize the following guidelines. Upon receiving the bids, the owner should review the bids based on the selection criteria listed in the tender documents without directly engaging in discussion of the bids with any of the bidders. An owner may obtain clarification on submitted bids but should not engage in any form of negotiation with any of the bidders prior to short listing to avoid raising concerns of procedural fairness unless it negotiates or clarifies with all bidders in a consistent manner. If an owner were to engage in negotiation with a bidder at this stage of the process, other bidders may argue that they would have been able to offer similar concessions if they had also been given an opportunity to negotiate with the owner. Once all bids have been reviewed, the owner can prepare a short list of bidders and then proceed to negotiate with the short listed bidders on the basis outlined in the bidding documents.

\section{ACCEPTING A Non-COMPliant BID}

While tender documents often contain express language allowing for the acceptance of non-compliant bids, the selection of non-compliant bids is the most common ground for litigation in tendering cases and owners should proceed with caution. In the ordinary course, a bidder that submits a non-compliant bid must be disqualified. The exercise by an owner of its right under a privilege clause to consider non-compliant bids may open such owner up to claims that another bidder's tender was not treated fairly and equally.

Language similar to that set out below is often incorporated into the call for tenders:

Tender forms, tender price forms, and enclosures that are improperly prepared may, in the Owner's sole and absolute discretion, be declared informal. Failure to provide the security deposit or comply with the insurance requirements, as required, may, in the Owner's sole and absolute discretion, result in the tender being declared informal.

$40 \quad$ The suggested language and all examples that follow are provided as illustrations only and are not intended to be relied upon as legal advice for all or any particular tendering process. Consultation with legal counsel is strongly recommended in each instance to ensure that instructions are drafted in a manner that best meets an owner's needs and objectives.

$41 \quad$ Toronto Transit Commission v. Gottardo Construction Limited (2003), 68 O.R. (3d) 356 (Sup. Ct. J.), aff'd (2005), 77 O.R. (3d) 269 (C.A.), leave to appeal to S.C.C. refused, 31194 (27 April 2006) [Gottardo] (second stage bidding created circumstances where the bidder was free to withdraw based on error in its initial bid. The Ontario Superior Court held the bidder was not obligated to enter into Contract B). 
The Owner may, in its sole and absolute discretion, retain or reject for its consideration bids that are nonconforming because they do not contain the content or form required by the bid documents or for failure to comply with the process for submission set out in the Instructions to Bidders. Without limiting the generality of the foregoing, bids that are incomplete, unsigned, improperly signed or sealed, conditional, contain arithmetical errors, obscure, illegible, or that contain entries not called for, erasures, alterations, or irregularities of any kind whatsoever, may, in the Owner's sole and absolute discretion, be considered informal. The Owner may, in its sole and absolute discretion, elect to retain for consideration and acceptance any bid that is informal or irregular, and the Owner may, in its sole and absolute discretion, waive any deviation, informality, or irregularity. ${ }^{42}$

Provisions giving an owner the right to accept non-compliant bids have been interpreted strictly by the courts. Tendering law jurisprudence contains numerous examples of disgruntled bidders suing owners on the basis that the selected bid was non-compliant. Typical examples of non-compliance include: (i) tenders not submitted before the close of tenders; (ii) tenders not submitted on the required tender form; (iii) tenders that do not provide all required information; (iv) qualified or conditional tenders; and (v) tenders that do not conform to the specifications required by the tender documents.

Some cases have stated that strict compliance with the requirements of a tender call is necessary in order to promote the integrity of the tendering process. ${ }^{43}$ However, other cases have held that so long as there is substantial compliance with the requirements of the tender call, the owner may overlook a minor error and accept an irregular tender. ${ }^{44}$ The Supreme Court of Canada has stated that the test of materiality of non-compliance is dependent on the unique facts of each case and the interpretation of the tendering documents. ${ }^{45}$

Before considering the acceptance of a non-compliant bid, an owner should carefully consider the nature and materiality of the non-compliance. Where an owner reserves the right to accept a non-compliant bid and the non-compliance is relatively minor or administrative in nature, an owner should not be open to a claim of unfair tender practices if it accepts such a bid. The Supreme Court of Canada has held that an "informality" is something that does not materially affect price or performance. ${ }^{46}$ For example, in Double $N$, failure to include licence and serial numbers for certain equipment in the bid submission was held to be a mere informality.

An owner may allow a bidder to cure a defect in its bid, provided this does not prejudice the interests of other bidders. For example, if multiple bidders make minor errors or mistakes with respect to the form of tender submitted and the owner allows such bidders to correct such errors and resubmit their bids prior to the close of tenders, it is unlikely that this would constitute a breach of the owner's duty of fairness. If an owner were to reopen the process for submission of bids, it should reopen the process to all bidders in order to ensure procedural fairness. However, if a bidder is allowed to submit a bid after the close of tenders, this will likely constitute a breach. In Vachon, the British Columbia Court of Appeal found 
that a privilege clause, which stated that irregularities contained in tenders could be considered informal, did not clothe the owner with a discretion to permit the correction of a price after the close of tenders. ${ }^{47}$

An owner should not accept bids where the non-compliance is of a fundamental nature, such as a bid being submitted after the close of tenders or where adherence to a Canadian Standards Association (CSA) standard cannot be given by a bidder, as such a standard has been held to be material because it pertains to safety. ${ }^{48}$

In order to reduce the potential for non-compliance or errors, owners should seek to minimize the number of specific items of information requested from bidders. Owners may also wish to consider inserting language specifically defining what will constitute "compliance" and "material deviation" versus informalities and "immaterial deviations" in the tendering process.

Owners are generally not required to look beyond the contents of the bid to ensure a bid is compliant with the tender requirements. ${ }^{49}$ Owners are entitled to rely upon bidders' representations on the face of the bid documents and generally do not have a duty to investigate the contents of a bid to ensure compliance with tender specifications. However, an owner is entitled to seek clarification in circumstances where information regarding noncompliance comes directly from the subcontractor and can choose to exercise its right to clarify and confirm the non-compliance before entering into Contract B. Therefore, if it is important to an owner that a contractor comply with a particular standard or possess particular qualifications, it is advisable that the owner seek evidence of those standards or qualifications as part of the bid or reserve its right to investigate and confirm that a bidder possesses such qualifications before selecting the successful bidder and entering into Contract B.

\section{Negotiating THE Terms OF Contract B}

An owner may want to be free to negotiate the terms of Contract B with the successful bidder upon completion of a short listing process. An owner can retain the ability to negotiate the terms of Contract B with its short listed bidders or a preferred bidder by including express language to this effect in the tender documents.

To preserve the ability to negotiate the terms of Contract B with the successful bidder, the following language could be incorporated into the call for tenders:

The successful bidder will, within [state period of time] of the date that the bidder is notified that its bid has been selected by the Owner, enter into the construction contract with the Owner. The terms of the construction contract may be materially altered as a result of negotiations between the Owner and the successful bidder, which negotiations will be conducted at the Owner's sole and absolute discretion. The

Vachon, supra note 24.

Cityscape Contracting Ltd. v. Edmonton (City of), 2007 ABQB 161, 416 A.R. 249.

Double N, supra note 45 at para. 119. 
unsuccessful bidders will not have a claim for breach of procedural fairness where the terms of the construction contract are materially altered from those set out in the tender documents.

The Owner may also negotiate the provisions of a tender with the respective tenderer prior to award of the construction contract, which negotiations may result in changes to a tender without entering into similar negotiations with any or all of the other tenderers.

Owner may, in its sole and absolute discretion, award the contract on viable terms acceptable to it by any tenderer or any other person. Owner's selection will be based on which tenderer or person has provided a tender which the Owner determines in its sole and absolute discretion to be most beneficial to Owner based on the criteria contained in the Instructions to Bidders and such other criteria as may be determined by Owner, from time to time. The acceptance of a tender or any part thereof shall be made in writing. After the selection of a tender, Owner has, in its sole and absolute discretion, the right to negotiate with the tenderer in question and, as part of that negotiation, to negotiate changes, amendments, or modifications to the tender as submitted, without offering other tenderers the opportunity to amend their tenders. Owner shall incur no liability to any tenderer as a result of these discussions, negotiations, or modifications. Such discussions and negotiations shall not affect the irrevocability of the tenders, which irrevocability shall remain in full force and effect, until such time as the tender is accepted, in whole or in part, or the tender expires or the tenderer and Owner mutually agree in writing on any modified terms as a condition to Owner's acceptance of such tender. $^{50}$

However, where the owner wishes to use a binding process, the owner should provide as much certainty with respect to the terms of Contract B during the process as possible in order to reduce the risk of having the process characterized as non-binding. The owner should include a draft copy of Contract B in the tender documents and request that bidders provide specific comments on such form of contract in its bid. By requiring bidders to submit their comments on such proposed terms as part of bid submission, a "battle of the forms" can be avoided. An owner can structure its tender process so as to retain the ability to negotiate the terms of Contract B provided, however, that a majority of and the fundamental Contract B clauses are not left open to negotiation. Examples of items that can be particularly contentious include milestone schedules, performance guarantees, liability and indemnity provisions, assignment, and termination rights. If time is of the essence in settling the terms of and executing Contract B, it is advisable that as few terms as possible are left open to discussion and negotiation.

In a recent decision, the Supreme Court of Canada found that an owner's obligations under Contract A to unsuccessful bidders, and in particular its implied obligation to treat bidders fairly, do not survive the creation of Contract B with the successful bidder ${ }^{51}$ and concluded that "[w]here an owner undertakes a fair evaluation [of the bids] and enters into Contract B on the terms set out in the tender documents, Contract A is fully performed. Thus, any obligations on the part of the owner to unsuccessful bidders have been fully discharged. Contract B is a distinct contract to which the unsuccessful bidders are not privy." 52 Accordingly, an owner is not compelled to insist on performance of Contract B in accordance 
with the tender specifications in order to meet its duty of fairness to the other bidders. Also, based on the reasoning of that decision, an owner should be entitled to amend Contract B to account for changes in conditions following the formal tender process. Moreover, this decision provides support for the proposition that owners can negotiate key terms with bidders prior to selecting the successful bidder (for example, asking a bidder to lower its price on a piece of equipment to match that of another bidder) so long as the tender documents expressly provide for the right to conduct such negotiations.

\section{E. The Privilege Clause}

A privilege clause may be incorporated into the tender documents to provide an owner with greater latitude in carrying out the tender process as it wishes, provided that express language is used. The legal effect of a clear and unambiguous privilege clause is that the lowest tender is not legally entitled to the award. ${ }^{53}$

Language similar to that set out below is often incorporated into the call for tenders:

The Owner is not bound to accept any bid and may proceed as it determines, in its sole and absolute discretion, following receipt of the bids. The Owner reserves the right, in its sole and absolute discretion, to accept or reject bids in whole or in part, to discuss different or additional terms to those included in the bid documents or in any bid, or to amend or modify any term of the bid documents. Without prejudice to this right, Owner may request clarification where any tenderer's intent is unclear and may, in its sole and absolute discretion, waive or request amendment where, in the opinion of Owner, there is an irregularity or omission in the information that is submitted in a tender.

The Owner makes no representations, covenants, warranties, or guarantees, express or implied, other than those expressly set forth herein. The Owner does not bind itself to accept the lowest or any bid. Implied warranties of acceptance of the lowest priced bid are specifically excluded.

The tender with the lowest quoted price will not necessarily be selected. While price is an important element in the selection process, it is to be clearly understood that there are many factors that Owner may, in its sole and absolute discretion, consider in evaluating one, some, or all of the tenders.

The Owner reserves the right to cancel this tender process, in its sole and absolute discretion, for any reason whatsoever without any obligation or any reimbursement to the bidders and, in its sole and absolute discretion, may issue another set of bid documents.

By submitting its bid in response to the call for tenders, the bidder expressly acknowledges and agrees that it shall have no claims against or entitlement to damages from the Owner of any kind whatsoever by reason of the Owner's rejection of its bid or all bids or acceptance of any other bid. ${ }^{54}$

A generally accepted practice that is based on custom or usage (such as the lowest tender must be accepted) will not supercede a clear and unambiguous privilege clause, so long as 
an owner has acted in good faith and fairly in relation to the tendering process. ${ }^{55}$ In addition to outlining the procedural framework of the tender process, the insertion of specific privilege clause language in the invitation for tenders can, among other rights, give an owner the express right to (i) not accept any bids submitted, (ii) cancel the tender process altogether or amend it at any time in its sole discretion, and (iii) select a bid other than the lowest bid.

A number of lower court decisions have held that an owner cannot rely on a privilege clause when it has not included all operative terms used in evaluating bids in the invitation to tender. ${ }^{56}$

It has been held that a privilege clause that reserves to the owner the right to reject any bid without giving reasons does not relieve the owner of its obligation to treat all bidders fairly. In Southside Construction (London) Ltd. v. 734133 Ontario Ltd., ${ }^{57}$ the Ontario Superior Court of Justice found that in failing to disclose material preferences for a local unionized contractor with whom the owner had previously worked, the owner had breached its obligation to act in good faith.

It has also been held that a privilege clause may not shield a tendering authority against an allegation of bad faith where the privilege clause does not reserve to the owner a right to reverse a decision made initially to reject a tender package submitted without the requisite corporate seal in accordance with the requirements of the terms of tender. ${ }^{58}$

In the case of Dolyn Developments Inc. v. Paradigm Properties Inc., ${ }^{59}$ the tender documents contained a privilege clause that reserved the right of the owner to accept or reject any or all tenders, and to not be obligated to accept the lowest bid. After tenders closed, the owner advised bidders that all bids received were in excess of the owner's budget and that all bids were rejected. The Ontario Superior Court of Justice held that the tendering process had been properly terminated and that the owner was free thereafter to contact a bidder that had participated in the terminated tender process and to enter into a contract with that bidder.

A privilege clause has also been held to not allow bid shopping or procedures akin to bid shopping. ${ }^{60}$

\section{F. BID SHOPPING}

Bid shopping was defined by the trial judge of the British Columbia Supreme Court in Stanco ${ }^{61}$ as follows: "[C]onduct where a tendering authority uses the bids submitted to it as

See Chinook, ibid.; Kencor Holdings Ltd. v. Saskatchewan (1991), 96 Sask. R. 171 (Q.B.) [Kencor Holdings]; Fred Walsh Ltd. v. B.G.M. Construction Ltd. (1996), 24 B.C.L.R. (3d) 52 (S.C.); George Wimpey, supra note 19; Martselos Services, supra note 17.

(2005), 45 C.L.R. (3d) 237 at para. 7 (Ont. Sup. Ct. J.).

Fullercon Ltd. v. Ottawa (City of) (2002), 41 B.L.R. (3d) 183 (Ont. Sup. Ct. J.), aff'd (2003), 44 B.L.R. (3d) 150 (Ont. C.A.), leave to appeal to S.C.C. refused, 30135 (29 April 2004).

(2007), 61 C.L.R. (3d) 295 (Ont. Sup. Ct. J.).

Twin City Mechanical v. Bradsil (1967) Ltd. (1996), 31 C.L.R. (2d) 210 (Ont. Ct. J. (Gen. Div.)) [Twin City]; Thompson Bros. (Const.) Ltd. v. Wetaskiwin (City of) (1997), 205 A.R. 185 (Q.B.) [Thompson Bros.].

61 Stanco Projects Ltd. v. British Columbia (Ministry of Water, Land and Air Protection), 2004 BCSC 1038, 32 B.C.L.R. (4th) 302 [Stanco]. 
a negotiating tool, whether expressly or in a more clandestine way, before the construction contract has been awarded, with a view to obtain a better price or other contractual advantage from that particular tenderer or any of the others." 62

The trial judge found that the owner had engaged in bid shopping as a bargaining tool to negotiate price following the close of tender and concluded that a privilege clause will not justify "bid shopping or procedures akin to bid shopping."63 The British Columbia Court of Appeal upheld the decision and emphasized the need for a court to assess the totality of an owner's conduct within the particular circumstances of each case when evaluating whether an owner has engaged in improper bid manipulation.

Courts in several cases have held that, where an owner applies a "secret preference" in evaluating and accepting a tender or is guilty of bid shopping, it cannot rely on the privilege clause in defence to a claim for breach of Contract $\mathrm{A}^{64}$

In Amber Contracting Ltd. v. Halifax (Regional Municipality), ${ }^{65}$ the Supreme Court of Nova Scotia held that the owner engaged in bid shopping in breach of its duty of fairness to all tenderers when it cancelled one tender for the work and then re-tendered essentially the same scope of work in an effort to secure a better price after public disclosure of the bid prices in the initial tender for the work.

Where a contractor used the pricing of the lowest bidder in a formal bidding process with its subcontractors to negotiate a lower price with two subcontractors for their work, the Ontario Superior Court of Justice held that the contractor's conduct created a "sham of the bidding process." 66 This conclusion was based on evidence of the subcontractor that the lowest bidder was normally awarded the contract and was obligated to carry out the work at the bid price. The contractor was found in breach of its duties under the contract for bid shopping.

\section{G. GUIDELINES FOR THE TENDER PROCESS AND DRAFTING OF TENDER DOCUMENTS}

If a dispute arises in the tendering process, the courts will examine the terms and conditions contained in the tender documents in each individual case. ${ }^{67}$ Tendering cases are usually decided on the basis of a court's interpretation of the terms contained in the call for tenders. As such, the rights and obligations of the parties under Contract A, and indeed whether and when Contract $\mathrm{A}$ is formed, all depend on an interpretation of the terms and conditions of the tender call. For this reason, it is of critical importance that an owner carefully consider and draft the language in its invitation for tenders.

\footnotetext{
$62 \quad$ Ibid. at para. 100.

$63 \quad$ Ibid. at para. 90, citing M.J.B. Enterprises, supra note 3 at para. 50

$64 \quad$ Chinook, supra note 15 at 297; Kencor Holdings, supra note 56; George Wimpey, supra note 19; Thompson Bros., supra note 60; Twin City, supra note 60; Tarmac Canada Inc. v. Hamilton-Wentworth (Regional Municipality) (1999), 48 C.L.R. (2d) 236 (Ont. C.A.).

652008 NSSC 208, 267 N.S.R. (2d) 44.

$66 \quad$ See A. Dynasty Roofing (Windsor) Ltd. v. Marathon Construction Services (1991) Inc. (2002), 16 C.L.R. (3d) 43 at para. 11 (Ont. Sup. Ct. J.). Ron Engineering, supra note 1.
} 
The following is a list of general guidelines that owners should follow in respect of the tender process and drafting of tender documents:

- $\quad$ The invitation for bids must state the number of days the bid will remain open for acceptance following the opening of bids.

- The tender documents should avoid the use of too many blanks or requesting too much information. If cost breakdown or unit price information is sought, the owner should consider requesting this information after Contract B has been signed in order to reduce the possibility of errors.

- The tender documents should clearly state whether the bid price includes GST, PST, other applicable taxes, permit fees, and so on. If separate statements of these amounts are desired, the boxes or blanks on the bid form should be clearly labelled in order to avoid confusion.

- The tender documents should specify and be consistent as to the nature of the procurement process. If the owner is using a binding, competitive bidding process, obligations of the owner and the bidders should be set out. If the owner is using a non-binding negotiation, then the tender documents must be clear and uniform in this approach.

- Where an owner wishes to use a binding tender process, the invitation for tenders should mandate that bids are irrevocable upon submission and binding upon acceptance and that bidders are obligated to enter into Contract B if selected. The binding nature of the bid can be further reinforced by requiring bidders to submit a deposit, bid bond, or other security and providing that a bidder forfeits its deposit or other security if it revokes its bid or refuses to enter into Contract B. The amount of the deposit, bid bond, or other security should always be a percentage of the tender price. Describing the bid bond as an amount in one section of the tender documents and as a percentage in another section opens the tender documents up for greater possibility of error. ${ }^{68}$

- $\quad$ The call for tenders should provide a formal evaluation process whereby the owner can request bidders to clarify or correct deficiencies or non-conformities in their bids. This allows the owner to work with parties to cure defects in their bids. Such process must be implemented carefully to ensure that revisions to tendered bids do not prejudice the interests of other bidders. An entitlement to correct an irregularity does not go so far as to grant the ability to amend the bid after closing. ${ }^{69}$ A curing provision should only allow for the modification and correction of minor errors in the bid. 
- The tender documents should clearly list all criteria to be considered in selecting the successful bidder and awarding Contract B. The privilege clause should contain an extensive list of selection criteria in order to provide the owner with flexibility in selecting bids on considerations other than price. Selection criteria can include, among other items, bidder's expertise, safety record, financial situation, access to funds, previous involvement in bankruptcy or insolvency proceedings, claim history, reputation, project price/cost, the quality of construction materials to be used, and projected work completion date and schedule. An owner must ensure that it treats all bidders fairly by evaluating all bids based on the general terms and specific selection criteria it lists in the tender documents.

- $\quad$ Owners should carefully consider what specific requirements should be requested from the bidders. The more detail that is required in tender documents, the more scope exists for bidders to have errors in their bids or to be unable to comply with specific requirements. Where an owner does not intend to confirm the information set out in the specific requirements, it should avoid asking for those requirements.

\section{OBLigations OF BIDDERS}

\section{A. Submitting A Compliant Bid}

A bidder has certain obligations to the owner in the tendering process. During bid submission, a bidder must carefully comply with the instructions set out in the tender documents and submit a compliant bid. As the current state of the markets and the delay and cancellation of many oil, gas, and oilsands projects will result in greater competition for available work and projects, bidders are likely to be more cognizant of the fact that submitted bids need to be compliant in order to avoid disqualification.

\section{B. IRREVOCABILITY}

Irrevocability is often a term of Contract A that requires the bidder to honour its bid for a stated period of time; no withdrawal of its bid will be permitted during such period.

\section{CoRrecting TENDER DEFICIENCIES AND ERRORS}

A situation could arise where a bidder alleges that its bid contains an error and that, therefore, its bid is not open for acceptance. In Calgary (City of) v. Northern Construction Co. Division of Morrison-Knudsen Co., ${ }^{70}$ the Alberta Court of Appeal considered the issue of withdrawal by a tenderer of its tender. In that case, the owner refused to permit the withdrawal of a tender that contained an error, an inadvertent transposition of numbers, by the tenderer. The owner awarded the contract to this tenderer, who subsequently refused to enter into Contract B at the mistaken price. The Alberta Court of Appeal applied the Contract A/Contract B analysis from Ron Engineering and found that the tenderer was liable for damages equal to the difference between its tender price and that of the next lowest tenderer, who was subsequently awarded Contract B. 
Note that it has been held that an owner cannot accept a tender where a contractor error is apparent on the face of the tender. ${ }^{71}$

The Ontario Court of Appeal has held that where an owner is unaware of a bidder's mistake and does not act fraudulently or contribute to the error, and where the bidder fails to prove that it would suffer unconscionable financial harm if it is held to its bid, equity will not intervene. ${ }^{72}$ Thus, the bidder may be held to its bid even in the face of an error where the error is not apparent on the face of the tender.

\section{SUBCONTRACTOR/SUB-CONSULTANT WORK}

A bidder should also beware of being bound to the terms of its bid submission to the extent it relates to work to be provided by subcontractors or sub-consultants. The Supreme Court of Canada has held that an owner in a tendering process does not owe a duty of care in tort to subcontractors. ${ }^{73}$

\section{BIDDING THROUGH A JOINT VENTURE}

If a tender or RFP process permits bids or proposals to be submitted by a joint venture, each party to the joint venture should ensure that the other party or parties to the joint venture are qualified to participate in the tendering or RFP process. Consideration should also be given to whether the assessment of certain selection criteria is based on the evaluation of the joint venture as a whole or based on each party individually in proportion to its respective interest in the joint venture. Prior to entering into such a process, parties to a joint venture should determine whether mechanisms are in place to permit a party to withdraw from the joint venture and the associated difficulties that may arise relative to the tendering or RFP process as a result. If the tendering process is a multi-stage process that is scheduled over a lengthy period of time, it may be prudent to clarify with the owner that the definitive agreement may be entered into by any party to the joint venture if the bid or proposal was submitted in the name of the joint venture but the joint venture ceases to exist at the time that the definitive agreement is to be entered into.

An owner that receives a bid or proposal from a joint venture should require complete disclosure of all parties to the joint venture in order to have a complete listing of the bidders involved in the tender process and to ensure compliance with any qualification criteria. If one party to the joint venture is to act as agent on behalf of the joint venture during the bidding and subsequent work execution phases, documentation evidencing this agency arrangement should be provided to the owner as part of the bid submission. 


\section{THE JOINT VENTURE AS OWNER}

Procurement activities undertaken by the operator of a joint venture may be subject to specific provisions contained in an operating procedure governing joint operations, the joint venture agreement, or expressly addressed in a detailed construction, ownership, and operation (CO\&O) agreement. This is especially true for capital intensive projects. CO\&O agreements often include subcontracting clauses stating that the operator may subcontract its duties and responsibilities to a subcontractor with operating committee approval, provided that the operator retains full control and supervision of the subcontractor.

The Association of International Petroleum Negotiators' Model Joint Operating Agreement ${ }^{74}$ contains language that can be incorporated into an operating procedure or joint venture agreement whereby the particular procedure to be followed in respect of contract awards can vary based on the type of operation being conducted as well as the anticipated cost of such operation.

A party that is the operator of a joint venture should consider any obligations it may be required to fulfill during the contract award process. An operator may be obligated to award a contract to the best qualified contractor as determined by cost and ability or to conduct a particular form of formal tender process. If an operator is required to undertake an extensive tender process, the operator may be required to deliver a competitive bid analysis (including its recommendation and reasons for the award) to the joint venture parties. The joint venture agreement, operating procedure, or CO\&O agreement may also contain restrictions in respect of contracting with an affiliate and the actual award of a contract to a bidder may be subject to the approval of an operating committee.

Parties to a joint venture should consider what degree of discretion the operator should have in respect of awarding contracts and whether it is desirable to include detailed guidelines in the governing operating procedure or joint venture agreement that must be followed.

\section{COMPANIES' CREDITORS ARRANGEMENT ACT IMPlications on THE TENDERING Process}

Special considerations arise in a situation where an owner undertaking a tendering process is itself subject to CCAA proceedings. In this case, an owner will want to preserve flexibility to dispose of its business, including the tendering process and any submitted bids or Contract $\mathrm{B}$, if awarded and executed, to a successful purchaser. The owner will also want to preserve some flexibility for the successful purchaser to negotiate the terms and conditions of Contract B with the successful bidder following such purchaser's acquisition of the business if not already executed. In a CCAA process, receiving binding bids while maintaining flexibility in the process are important objectives. A binding tender process will attain certainty of bidder and the resulting performance of Contract B and, properly drafted, can reserve the desired flexibility through the use of express language in the tender documents. 
An owner subject to CCAA proceedings must obtain court approval prior to inviting tenderers to bid and before award and execution of Contract $B$. The court approval process is advantageous to an owner and a purchaser of the owner's business, if applicable, as the court approval process can vest title to the owner's assets in a subsequent purchaser free from all claims by any bidders relating to the tender process, provided that the owner, in seeking such approval, ensures that:

1. all bidders are given notice of the motion relating to the request for an acknowledgment from the court approving the award of Contract B to the selected bidder; and

2. such acknowledgment states that all steps of the tendering process have been complied with, that the tendering process has been conducted in a fair and reasonable manner, and that there shall be no claims made against the owners or its assets in respect of such tendering process or the award of Contract B.

The monitor will be involved in and oversee the tendering process and will be specifically responsible for reporting to the court and confirming that the owner has conducted the tendering process in compliance with the tender documents and in a fair and reasonable manner. The owner should meet with the monitor early in the process to discuss the role of the monitor in the tendering process. In addition, specific language should be included in the tender documents outlining the role and responsibilities of the monitor in the tendering process for potential bidders.

\section{DAMAgES AND LiMitation OF LiABILITY}

\section{A. Claim by BIDDER}

If a bidder is of the view that there has been a breach by an owner of its Contract $\mathrm{A}$ obligations, that bidder may bring an action for damages against the owner for which the owner could be liable. This will likely become an important consideration in the future as contractors competing for less work in the oil, gas, and oilsands industries may be more inclined to bring claims against owners where there is even the slightest hint that an owner did not comply with its obligations. A limitation of liability clause in the tender documents is therefore of critical importance.

An exclusion clause is different from a privilege clause in that an exclusion clause is often a broadly worded clause that expressly limits the liability of the owner whereas a privilege clause must contain specific language in order to give the owner the express right to conduct the process in a certain manner and prevent the owner from otherwise being obligated to accept the lowest bid or any tender at all.

In Port Hawkesbury, the Nova Scotia Court of Appeal found that a clause that stated that "the Owner reserves the right to reject any and all Tenders that, in its sole discretion, are not 
in the interests of the [owner]" did not give the owner "an unfettered discretion to simply disregard the rights and interests of the [bidder] in the tendering process."

Although courts will conservatively interpret privilege clauses, a properly worded exclusion clause can effectively limit an owner's liability for damages for breach of its Contract A obligations. In Tercon, ${ }^{76}$ the British Columbia Court of Appeal overturned a lower court decision and held that an owner in an RFP process (which was interpreted to be a tender call in substance) could be absolved of liability for selecting a non-compliant bidder on the basis that the tender documentation contained an exclusion clause absolving the owner from any liability for defects. The clause in question stated:

Except as expressly and specifically permitted in these Instructions to Proponents, no Proponent shall have any claim for any compensation of any kind whatsoever, as a result of participating in this RFP, and by submitting a proposal each proponent shall be deemed to have agreed that it has no claim. ${ }^{77}$

The Tercon case has been granted leave to appeal by the Supreme Court of Canada and, accordingly, there will be more definitive consideration of the enforceability of such provisions. In light of the uncertainty created by leave being granted, it may be beneficial for owners to consider proper management of risk rather than its elimination. Instead of asserting that the owner will assume no liability to the bidder for any irregularity, it may be better to limit the damages payable for a Contract A breach to a realistic figure ${ }^{78}$ For example, in Elite Bailiff Services Ltd. v. British Columbia, ${ }^{79}$ the British Columbia Court of Appeal found that a clause limiting damages for a Contract A breach would apply even to an egregious breach.

\section{B. Claim BY OWNER}

Where a bidder breaches Contract A, an owner may claim against any deposit, bid bond, or other security provided by a bidder in conjunction with its bid, subject to any defences that may be available to a bidder. Defences to such a claim include failure by an owner to award during the bid acceptance period in breach of the terms of Contract A. Another defence that a bidder may be able to rely on is limitation of actions under the bid bond or other security. Often the form of bid bond provides that suits under the bid bond must be instituted within a certain period of time from the date of the bond and only cover certain liabilities of the bidder. A bidder may also be able to argue that the owner is estopped by its own conduct from subsequent claims for damages and bid bond forfeiture. This may be raised where an owner allows a tenderer to withdraw a tender containing an error or gives the bidder assurances that recourse to the bid bond or other security will not be taken.

Port Hawkesbury, supra note 25 at paras. 30-31.

Tercon, supra note 34 .

Ibid. at para. 10.

David R. Percy, “The Law of Tenders” (Paper prepared for the Legal Education Society of Alberta, Construction Law Seminar, April 2009) [unpublished].

2003 BCCA 102, 10 B.C.L.R. (4th) 264 at para. 34. 


\section{Conclusion}

Owners must be aware of the legal duties and obligations involved in all types of tendering processes before engaging in them and carefully consider such duties and obligations when structuring their projects in Canada.

Consideration of project objectives and goals is critical to determine the most effective procurement process: will the binding nature of the procurement process be more important than the ability to maintain flexibility or vice versa? Additionally, is some form of RFEI process, RFQ process, or a pre-qualification process prior to a formal tender or RFP process advantageous? As multi-stage procurement processes allow oil, gas, and oilsands producers to manage the planning, development, cost management, and coordination of their medium and large-scale projects in a more effective manner, these or hybrid processes will continue to have appeal. Pre-qualification will likely become more important in the future as contractors compete for fewer projects and less work in the oil, gas, and oilsands industries.

Where a formal tender process is utilized, an owner must ensure that all bidders are treated fairly and equally. This is an especially important consideration for producers who wish to avoid claims from disgruntled service providers who may already be competing for less work in the petroleum industry. While an owner can structure its tender process to meet its needs, owners should be aware of the risks associated in doing so. Owners can use a short list process by expressly including appropriate language in the tender documents to allow for such a process. However, the use of a multiple stage tender process may raise the risk that bidders disengage from the process during an initial non-binding stage, and an owner may potentially increase the risk of process claims from bidders due to increased uncertainty and greater complexity in the process.

While tender documents often contain express language allowing for the acceptance of non-compliant bids, the selection of non-compliant bids is the most common ground for litigation in tendering cases and, accordingly, owners should proceed with caution. Owners should only select bids that are compliant or contain deviations that are minor or administrative in nature. Acceptance of bids that contain deviations of a fundamental or material nature open an owner up to risk of claims for breach of procedural fairness by unsuccessful bidders. Owners can retain the ability to negotiate the terms and conditions of Contract B with a short list of bidders or a preferred bidder by including express language to this effect in the tender documents. However, owners should provide as much certainty with respect to the terms of Contract B as possible in order to reduce the risk of having the process characterized as non-binding and to expedite the negotiation and execution of Contract B.

A privilege clause containing specific language should be included in tender documents to enable an owner to carry out the tender process in the manner that it chooses. If appropriate, owners should include express language giving the owner the express right to accept a bid other than the lowest bid, to not accept any bid, and to cancel or alter the tender process in its sole discretion. 
It is important for owners and bidders to be familiar with their respective rights and obligations in respect of a procurement process prior to engaging in such process. Owners and bidders should also carefully abide by their respective Contract A obligations and duties in order to avoid having an action in damages brought against them. Special considerations will apply where bids or proposals are submitted as a joint venture or where an owner (as operator of a joint venture) undertakes procurement activities. An owner that is subject to CCAA proceedings during a tendering process will also need to structure the process to achieve bidder certainty while at the same time maintaining as much flexibility as possible for itself and the potential successor to the business of such owner. 